\title{
Antibodies to Tumor Necrosis Factor- $\alpha$ : Use as Adjunctive Therapy in Established Group B Streptococcal Disease in Newborn Rats
}

\author{
LAURENCE B. GIVNER, LATANYA GRAY, AND T. MICHAEL O'SHEA \\ Department of Pediatrics, Bowman Gray School of Medicine, Wake Forest University, Medical Center \\ Boulevard, Winston-Salem, North Carolina 27157
}

\begin{abstract}
Group B Streptococcus (GBS) is the leading cause of neona-
Group tal sepsis. Adjunctive therapies are being sought to improve the outcome. Because increased blood levels of tumor necrosis factor (TNF)- $\alpha$ may play a role in the development of sepsis and an adverse outcome thereof, we evaluated the potential use of antibodies against TNF- $\alpha$ as adjunctive therapy of GBS sepsis. Using a neonatal rat model of GBS sepsis, we measured serum levels of TNF- $\alpha$. Levels of TNF- $\alpha$ were significantly increased beginning $12 \mathrm{~h}$ after GBS inoculation and remained significantly increased at 30-36 h. We then examined the use of adjunctive therapy with antibody to TNF- $\alpha$ in animals with established GBS sepsis using polyclonal rabbit antirecombinant mouse TNF- $\alpha$ antiserum. Twelve hours after GBS inoculation, animals received a single dose of antibody to TNF- $\alpha$ or normal rabbit serum, and
\end{abstract}

penicillin therapy (twice a day for $3 \mathrm{~d}$ ) was begun. Animals receiving penicillin and antibody to TNF- $\alpha$ had a survival rate of $52 \%$ (13 of 25 ) versus $29 \%$ (7 of 24 ) for animals receiving penicillin and normal rabbit serum. Thus, the use of antibodies directed against TNF- $\alpha$ may have a role as adjunctive therapy of established GBS sepsis in the newborn infant. (Pediatr Res 38: 551-554, 1995)
CFU, colony-forming units
GBS, group B Streptococcus
i.p., intraperitoneal
TNF, tumor necrosis factor

GBS is the most common cause of life-threatening infection in newborns in this country (1). In spite of attempts at early diagnosis, the use of antimicrobials with rapid bactericidal activity in vitro, and the most technologically advanced intensive care support, morbidity and mortality rates continue to be unacceptable. Approximately 10-15\% of GBS-infected newborns die, and of those with meningitis about $50 \%$ of survivors are left with serious neurologic sequelae $(2,3)$. Thus, adjunctive therapies are being sought that would improve the outcome of GBS infection in newborn infants.

$\mathrm{TNF}-\alpha$ is a proinflammatory cytokine, produced in the host in response to infection. When produced in small quantities, it may have a beneficial effect on outcome; however, when produced in excessive amounts, it appears to adversely affect outcome. Levels of TNF- $\alpha$ generally have been noted to be elevated in humans during sepsis. As in adults, in children with severe sepsis due to a variety of Gram-positive or -negative bacteria, studies have dem-

Received January 6 1995: accepted May 11, 1995.

Correspondence and reprint requests: Laurence B. Givner, M.D. Department of Pediatrics, Bowman Gray School of Medicine, Medical Center Boulevard, Winston-Salem, NC 27157.

Supported in part by The Brenner Children's Hospital Fund.

This work was presented in part at the Annual Meeting of the Society for Pediatric Research, May 7-11, 1995, San Diego, CA. onstrated that higher blood TNF- $\alpha$ levels are associated with higher fatality rates $(4,5)$. A recent study $(6)$, however, did not find increased TNF- $\alpha$ levels in infants with sepsis due to a variety of Gram-positive or -negative bacteria; these infants were primarily preterm with late-onset, hospital-acquired infections (which may be less likely to be life-threatening).

Group B streptococcal infection has been shown to increase serum TNF- $\alpha$ levels in animals (7-9) and in human infants (10). In the present studies, using an experimental model, we evaluated the potential of antibodies directed against TNF- $\alpha$ for use as adjunctive therapy (with antibiotics) for established sepsis due to GBS in neonates.

\section{METHODS}

Bacteria. Originally isolated (by Dr. Carol Baker, Houston, TX) from the cerebrospinal fluid of a newborn infant, GBS type III strain M732, has been well characterized and used in previous studies (11). The bacteria were incubated at $37^{\circ} \mathrm{C}$ in Todd-Hewitt broth (Becton Dickinson, Cockeysville, MD) to log phase growth and then stored in aliquots at $-70^{\circ} \mathrm{C}$ until use. Before use, the bacteria were incubated overnight on blood agar at $37^{\circ} \mathrm{C}$. The bacteria then were incubated in Todd-Hewitt broth at $37^{\circ} \mathrm{C}$ to $\log$ phase growth, washed three times, and 
resuspended in PBS to a concentration of $1 \times 10^{5} \mathrm{CFU} / 0.02$ $\mathrm{mL}$.

Penicillin. Aqueous sodium penicillin G powder (Squibb, Princeton, NJ) was reconstituted in sterile water and stored in aliquots at $-70^{\circ} \mathrm{C}$ until use.

Antibody to TNF- $\alpha$. Polyclonal rabbit antirecombinant mouse TNF- $\alpha$ antiserum (Genzyme, Cambridge, MA) was purchased for use. This product has been shown by others to neutralize rat TNF- $\alpha$ (8). Normal rabbit serum was purchased from Sigma Chemical Co. (St. Louis, MO).

Measurement of TNF- $\alpha$ levels. A commercially available ELISA kit (Factor-Test mTNF- $\alpha$; Genzyme) was used. The lower limit of detection of this assay is $0.1 \mathrm{ng}$ of TNF- $\alpha / \mathrm{mL}$. Undetectable TNF- $\alpha$ levels were assigned a value of 0 . All specimens were tested in duplicate, and the results are expressed as the mean.

Measurement of endotoxin levels. A commercially available Limulus amebocyte lysate assay kit (E-Toxate; Sigma Chemical Co.) was used. The lower limit of detection with this assay is 0.05 endotoxin units $/ \mathrm{mL}$. Endotoxin levels were measured in samples of each reagent (including penicillin, polyclonal rabbit antirecombinant mouse TNF- $\alpha$ antiserum, and normal rabbit serum), selected serum samples (including those with measurable TNF- $\alpha$ levels) and GBS suspensions; all were negative.

Animal model of GBS infection. The animal model used was similar to that described by us previously (11). Outbred Sprague-Dawley timed-pregnant rats (Harlan Sprague-Dawley, Indianapolis, IN) were received in our animal care unit at least five days before delivery. Newborn rats $(<72 \mathrm{~h}$ old $)$ from multiple litters were randomly assigned to each study group. All injections were given using repeating dispensers and gastight syringes (Hamilton, Reno, NV). After injections, the pups were marked and returned randomly to the mothers.

The newborn rats received GBS, $1 \times 10^{5} \mathrm{CFU}$ sc just cephalad to the tail. Using this model, we have shown that $100 \%$ of animals are bacteremic $12 \mathrm{~h}$ postinoculation (11). In the present studies, beginning $12 \mathrm{~h}$ post GBS inoculation, the animals received penicillin, $100 \mathrm{mg} / \mathrm{kg}$ body weight per dose given twice daily for $3 \mathrm{~d}$ s.c. over the shoulders, or an equal volume $(0.02 \mathrm{~mL})$ of sterile water. At the time of the first dose of pencillin (or sterile water), the animals received polyclonal rabbit antiserum to murine TNF- $\alpha$, or normal rabbit serum, each at a dose of $0.04 \mathrm{~mL}$. In the studies of Teti et al. (8), 0.05 $\mathrm{mL}$ of rabbit anti-murine TNF- $\alpha$ serum (Genzyme) neutralized serum TNF- $\alpha$ in GBS-infected newborn rats. In the current studies, the sera were administered by the intraperitoneal (i.p.) route [i.p. administration of antibody to TNF- $\alpha$ has been shown to be efficacious in decreasing mortality in newborn rats after s.c. inoculation of Pseudomonas (12)]. To examine the effects on mortality, we evaluated three study groups: 1 ) penicillin and normal rabbit serum, 2) penicillin and polyclonal rabbit antiserum to murine TNF- $\alpha$, and 3) sterile water and polyclonal rabbit antiserum to murine TNF- $\alpha$. After infection, dead animals were removed from the cages frequently and mortality assessed every $12 \mathrm{~h}$. In our previous studies using a similar model (11), deaths in penicillin-treated animals most frequently occurred either soon after the initiation of antibiotic therapy or days after the completion of therapy. In the present studies, the animals were observed subsequent to this time until there had been no new illness or death noted for at least $48 \mathrm{~h}$.

In separate studies, blood was obtained from rats for measurement of TNF- $\alpha$ levels. The animals were placed on ice until inactive and then blood was obtained by cardiac puncture using a 20 -gauge needle. Immediately after cardiac puncture, the animals were killed by decapitation. After centrifugation, the serum specimens were stored at $-70^{\circ} \mathrm{C}$ until assayed in batches. For measurement of TNF- $\alpha$ levels, blood was obtained from uninfected animals, from animals infected and untreated, and from GBS-infected animals treated as outlined above with either penicillin or polyclonal rabbit antiserum to murine TNF- $\alpha$.

Statistical analyses. Group differences in TNF- $\alpha$ levels were analyzed using the Wilcoxon Rank sum test. Mortality was examined graphically using Kaplan-Meier survival curves. Survival curves were compared using a variation of the Wilcoxon rank test modified for censoring and the log rank test (13). The former is influenced more by mortality earlier in follow-up, whereas the latter is influenced more by mortality later in follow-up (14). All analyses were performed using PC-SAS (15). $p$ values $<0.05$ were considered significant.

\section{RESULTS}

Levels of TNF- $\alpha$. Normal rabbit serum contained no detectable TNF- $\alpha$. In 40 uninfected rats $(<72 \mathrm{~h}$ to $6 \mathrm{~d}$ old $)$, serum levels of TNF- $\alpha$ were undetectable.

In GBS-infected and untreated animals, serum TNF- $\alpha$ levels were measured before and then every $6 \mathrm{~h}$ after GBS inoculation (Fig. 1). Blood was obtained from five animals at each time until 30 and $36 \mathrm{~h}$ postinfection, when due to limited survival, three specimens were obtained at each time. As the TNF- $\alpha$

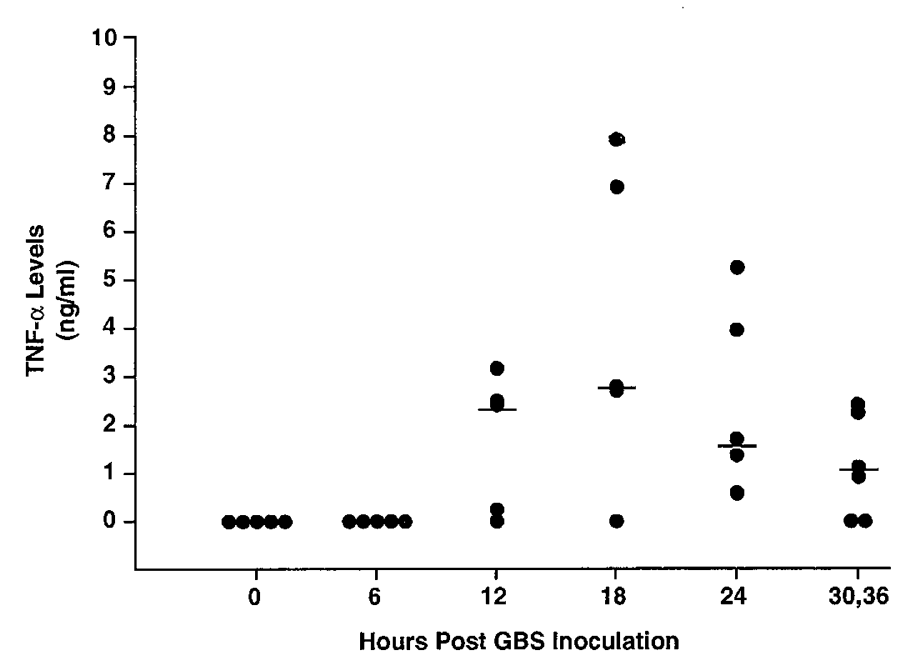

Figure 1. Serum levels of TNF- $\alpha$. Newborn rats were inoculated sc with $1 \times$ $10^{5} \mathrm{CFU}$ GBS and then blood was obtained at the times indicated. Five rats were studied at each time period, except 30 and $36 \mathrm{~h}$ postinoculation when, due to limited survival, three animals were studied at each time. As the TNF- $\alpha$ levels at 30 and $36 \mathrm{~h}$ appeared similar, the data at these time points was combined for statistical analysis. The bar represents the median value in each group. Compared with TNF- $\alpha$ levels before GBS inoculation, $p=0.02$ at 12 $\mathrm{h}$ and at $18 \mathrm{~h}, p=0.005$ at $24 \mathrm{~h}$, and $p=0.04$ at $30-36 \mathrm{~h}$. 
levels at 30 and $36 \mathrm{~h}$ appeared similar, the data at these time points was combined for statistical analysis.

As shown in Figure 1, the levels of TNF- $\alpha$ remained undetectable $6 \mathrm{~h}$ after GBS inoculation. The TNF- $\alpha$ levels were significantly increased at $12 \mathrm{~h}$ (median, range; $p$ value compared with preinoculation) (2.39 ng/mL, $0-3.13 ; p=0.02)$, and remained significantly increased at $18 \mathrm{~h}(2.79,0-7.91 ; p=$ $0.02), 24 \mathrm{~h}(1.69,0.57-5.24 ; p=0.005)$, and 30-36 h (1.02, $0-2.39 ; p=0.04)$ postinoculation.

In animals treated with penicillin beginning $12 \mathrm{~h}$ after GBS inoculation, TNF- $\alpha$ levels were measured $6,12,24$, and $36 \mathrm{~h}$ after initiation of penicillin therapy. All animals ( $n=4$ or 5 per group) had undetectable TNF- $\alpha$ levels. In GBS-infected animals receiving only polyclonal rabbit antiserum to murine TNF- $\alpha$, TNF- $\alpha$ levels were measured in five animals each at 6 and $12 \mathrm{~h}$ after therapy, and all were undetectable, documenting that the amount of antibody to TNF- $\alpha$ administered to GBSinfected animals was adequate to neutralize serum TNF- $\alpha$ at these times. Measurement of TNF- $\alpha$ levels in this group beyond these times ( $>12 \mathrm{~h}$ after therapy or $>24 \mathrm{~h}$ postinfection) was not possible due to limited survival (and the high cost of antibody to $\mathrm{TNF}-\alpha$ ).

Mortality studies. In preliminary studies, after s.c. injection of $1 \times 10^{5}$ CFU GBS, none of 35 animals survived (almost all deaths occurred within $36 \mathrm{~h}$ ); among GBS-infected animals treated with penicillin (as outlined), 32\% (19) of 60 animals survived.

The results of subsequent studies evaluating the effect of adjunctive therapy with antibody to TNF- $\alpha$ are shown in Figure 2. Among animals that received penicillin therapy (and normal rabbit serum), 7 (29\%) of 24 animals survived the study period. When polyclonal rabbit antiserum to murine TNF- $\alpha$. was given as adjunctive therapy with penicillin, 52\% (13) of 25 animals survived. Comparing the survival curves of these two groups yields $p=0.04$ using the Wilcoxon rank test modified for censoring and $p=0.06$ using the log rank test. Inspection of the two survival curves indicates that adjunctive therapy with antibody to TNF- $\alpha$ compared with penicillin alone improved survival early (in the first $36 \mathrm{~h}$ ) after administration, and that mortality risk in the two groups was similar after that time.

Without penicillin, none of 26 animals receiving polyclonal rabbit antiserum to murine TNF- $\alpha$ survived more than $24 \mathrm{~h}$ after therapy ( $36 \mathrm{~h}$ after GBS inoculation). Comparison of the survival curve of this group to that of the group that received antibody to TNF- $\alpha$ and penicillin yielded $p=0.0001$.

\section{DISCUSSION}

In animals, i.v. injection of TNF- $\alpha$ causes fever, metabolic acidosis, capillary leak, cardiovascular collapse and death, similar to that seen in septic shock $(16,17)$. In animal models of infection, it has been shown that serum TNF- $\alpha$ levels increase, and in some of these models, the administration of antibodies directed against TNF- $\alpha$ has been shown to improve outcome (reviewed in Ref. 18). Thus, using an experimental model, we studied the potential of antibodies directed against

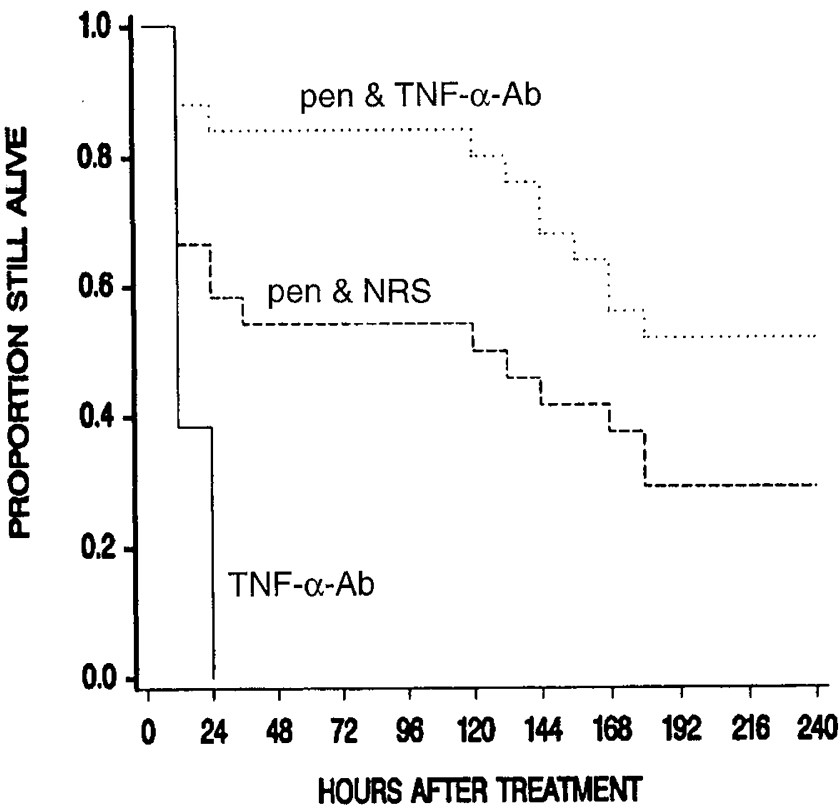

Figure 2. Adjunctive therapy with TNF- $\alpha$ antibody. Neonatal rats were infected sc with $1 \times 10^{5}$ CFU GBS and then $12 \mathrm{~h}$ later were given one of three treatments: a single ip dose of polyclonal rabbit antirecombinant mouse TNF- $\alpha$ (TNF- $\alpha-A b, n=26$ ); penicillin, $100 \mathrm{mg} / \mathrm{kg}$ body weight per dose, twice daily for three days s.c. over the shoulders and a single i.p. dose of normal rabbit serum given at the time of the first dose of penicillin (pen \& NRS, $n=24$ ); or penicillin and antibody to TNF- $\alpha$ as described (pen \& TNF- $\alpha-A b, n=25$ ). Comparing animals receiving penicillin and antibody to TNF- $\alpha$ to those receiving penicillin and normal rabbit serum, $p=0.04$ using a variation of the Wilcoxon rank test modified for censoring and $p=0.06$ using the log rank test. Comparing animals receiving penicillin and antibody to TNF- $\alpha$ to those receiving antibody to TNF- $\alpha$ alone, $p=0.0001$.

TNF- $\alpha$ for use as adjunctive therapy of established GBS infection in newborn infants.

In the present studies, neonatal rats had increased serum TNF- $\alpha$ levels beginning $12 \mathrm{~h}$ after GBS inoculation. The levels remained increased at 18,24 and $30-36 \mathrm{~h}$ (around the time that the last few surviving animals were near death) though levels at this latter time appeared to be approaching baseline levels. Our data are similar to those previously reported by Teti et al. (8); in their neonatal rat model, after i.p. injection of GBS, plasma TNF- $\alpha$ levels were significantly elevated at $12 \mathrm{~h}$, peaked at $20 \mathrm{~h}$, and decreased thereafter.

Previous studies also have evaluated the effect of antibodies directed against TNF- $\alpha$ on the survival of GBS-infected animals. In adult mice, rabbit anti-TNF- $\alpha$ serum, given $2 \mathrm{~h}$ before GBS inoculation, had no effect on survival even though it ablated the rise in serum TNF- $\alpha$ otherwise seen in response to infection (7). In the newborn rat, rabbit anti-TNF- $\alpha$ serum, given $2 \mathrm{~h}$ before and $26 \mathrm{~h}$ after GBS inoculation, significantly increased survival at $48-72 \mathrm{~h}$ but not at $96 \mathrm{~h}(8)$. However, in those studies $(7,8)$, antibodies to TNF- $\alpha$ were administered to the animals before the establishment of bacteremia, and antibiotics were not given. Thus, the use of antibodies against TNF- $\alpha$ in established GBS sepsis and in conjunction with antibiotics, as might be considered for the infant presenting with sepsis, had not been evaluated.

In the present studies, polyclonal rabbit antiserum to murine TNF- $\alpha$ administered after the establishment of bacteremia but 
without penicillin had no effect on survival of GBS-infected animals (all 26 animals died within the next $24 \mathrm{~h}$ ). Serum levels of TNF- $\alpha$ were already increased at the time of administration of the antiserum; however, the dose of antiserum given was enough to ablate the serum TNF- $\alpha$ levels seen thereafter in infected animals. It is not surprising that in the face of established bacteremia, antibody to TNF- $\alpha$ will not improve survival in the absence of antibiotic therapy.

In our model of established GBS sepsis, polyclonal rabbit antiserum to murine TNF- $\alpha$ used as adjunctive therapy with pencillin decreased mortality compared with normal rabbit serum and penicillin. This effect was noted during the first 36 $\mathrm{h}$ after administration. As mentioned above, other investigators (8) have observed that (in the absence of antibiotic therapy) rabbit anti-TNF- $\alpha$ serum, given $2 \mathrm{~h}$ before and $26 \mathrm{~h}$ after GBS inoculation of neonatal rats, significantly increased early survival (at 48 to $72 \mathrm{~h}$ ) but not final survival rates (at $96 \mathrm{~h}$ ). Of note, recently published are the results of a randomized, controlled, double-blind, multicenter trial of adjunctive therapy with a single dose of monoclonal TNF- $\alpha$ antibody in adults with sepsis syndrome (19). Among patients with septic shock, the use of TNF- $\alpha$ antibody was associated with a significant reduction in mortality three days after infusion; at $28 \mathrm{~d}$, a trend toward increased survival was noted, but this was not statistically significant.

As in the current studies, in our previous studies (11) using the newborn rat model of GBS sepsis, we administered penicillin every $12 \mathrm{~h}$ to GBS-infected rats. In the current studies, however, we extended the length of therapy from four to six doses (or $3 \mathrm{~d}$ ). This probably more closely simulates the length of therapy given to humans with GBS sepsis. In the animal model, continuing penicillin therapy even longer may prevent the late deaths noted days after completion of antibiotic therapy, and may result in further improvement in survival in the group receiving antibody to TNF- $\alpha$ as adjunctive therapy with penicillin (versus penicillin alone). This was not evaluated in the current studies nor was the effect of multiple doses of antibody to TNF- $\alpha$.

The mechanism of the protective effect of the antibody to TNF- $\alpha$ in penicillin-treated animals is not evident from the present studies. After initiation of treatment with penicillin, serum TNF- $\alpha$ levels were first measured $6 \mathrm{~h}$ later, when they were undetectable. We did not measure TNF- $\alpha$ levels earlier after initiation of therapy, thus, we do not know the effect of penicillin and/or antibody to TNF- $\alpha$ in this period. We also did not measure the effect of the therapies on other cytokines that may be important in the pathogenesis of septic shock and that may be affected by TNF- $\alpha$ levels, such as IL- 1 or IL- 6 (7, 8 , 20). Recently, in a neonatal mouse model of GBS sepsis, administration of recombinant IL- 6 was associated with decreased plasma TNF- $\alpha$ levels and improved survival time but not final survival rate (21).

The present studies suggest that antibody directed against TNF- $\alpha$ may have potential as adjunctive therapy of established GBS sepsis in the newborn infant. The use of such antibodies in infected newborn infants must be approached carefully, however $(10,18)$. TNF- $\alpha$ appears to play an important role in host defense against some pathogens, especially intracellular organisms, including Listeria monocytogenes (22), another Gram-positive bacterium that causes sepsis in newborn infants. Further, in some animal models of bacterial infection, the administration of antibodies against TNF- $\alpha$ has been shown to adversely affect outcome $(23,24)$. At this time, much further study is needed to explore the potential use of antibodies against TNF- $\alpha$ for adjunctive therapy of infection in newborn infants.

\section{REFERENCES}

1. Givner LB, Baker CJ 1988 The prevention and treatment of neonatal group B streptococcal infections. Adv Pediatr Infect Dis 3:65-90

2. Weisman LE, Stoll BJ, Cruess DF, Hall RT, Merenstein GB, Hemming VG, Fischer GF 1992 Early-onset group B streptococcal sepsis: a current assessment. J Pediatr 121:428-433

3. Edwards MS, Rench MA, Haffar AA, Murphy MA, Desmond MM, Baker CJ 1985 Long-term sequelae of group B streptococcal meningitis in infants. J Pediatr 106:717722

4. Sullivan JS, Kilpatrick L, Costarino AT Jr, Lee SC, Harris MC 1992 Correlation of plasma cytokine elevations with mortality rate in children with sepsis. J Pediatr 120:510-515

5. Girardin E, Grau GE, Dayer J-M, Roux-Lombard P, the J-5 Study Group, and Lambert P-H 1988 Tumor necrosis factor and interleukin-1 in the serum of children with severe infectious purpura. N Engl J Med 319:397-400

6. Harris MC, Costarino AT Jr, Sullivan JS, Dulkerian S, McCawley L, Corcoran L, Butler S, Kilpatrick L 1994 Cytokine elevations in critically ill infants with sepsis and necrotizing enterocolitis. J Pediatr 124:105-111

7. Teti G, Mancuso G, Tomasello F, Chiofalo MS 1992 Production of tumor necrosis factor- $\alpha$ and interleukin- 6 in mice infected with group B streptococci. Circ Shock 38:138-144

8. Teti G, Mancuso G. Tomasello F 1993 Cytokine appearance and effects of anti-tumor necrosis factor- $\alpha$ antibodies in a neonatal rat model of group B streptococcal infection. Infect Immun 61:227-235

9. Gibson RL, Redding GJ, Henderson WR, Truog WE 1991 Group B Streptococcus induces tumor necrosis factor in neonatal piglets. Effect of the tumor necrosis factor inhibitor pentoxifylline on hemodynamics and gas exchange. Am Rev Respir Dis 143:598-604

10. Williams PA, Bohnsack JF, Augustine NH, Drummond WK, Rubens CE, Hill HR 1993 Production of tumor necrosis factor by human cells in vitro and in vivo, induced by group B streptococci. J Pediatr 123:292-300

11. Givner LB, Nagaraj SK 1993 Hyperimmune human IgG or recombinant human granulocyte-macrophage colony-stimulating factor as adjunctive therapy for group B streptococcal sepsis in newborn rats. J Pediatr 122:774-779

12. Shi Y, Li H-Q, Shen C-K, Wang J-H, Pan J, Qin S-W, Liu R 1993 Association between protective efficacy of antibodies to tumor necrosis factor and suppression of nitric oxide production in neonatal rats with fatal infection. Pediatr Res 34:345-348

13. Kalbfleisch JD, Prentice RL 1980 The Statistical Analysis of Failure Time Data. John Wiley \& Sons, New York

14. Friedman LM, Furberg CD, Demets DL 1985 Fundamentals of Clinical Trials. PSG Publishing, Littleton, MA

15. SAS Institute 1990 Cary, NC

16. Tracey KJ, Beutler B, Lowry SF, Merryweather J, Wolpe S, Milsark IW, Hariri RJ, Fahey III TJ, Zentella A, Albert JD, Shires GT, Cerami A 1986 Shock and tissue injury induced by recombinant human cachectin. Science $234: 470-474$

17. Natanson C, Eichenholz PW, Danner RL, Eichacker PQ, Hoffman WD, Kuo GC, Banks SM, MacVittie TJ, Parrillo JE 1989 Endotoxin and tumor necrosis factor challenges in dogs simulate the cardiovascular profile of human septic shock. J Exp Med 169:823-832

18. Pennington JE 1993 Therapy with antibody to tumor necrosis factor in sepsis. Clin Infect Dis 17(suppl 2):S515-S519

19. Abraham E, Wunderink R, Silverman H, Perl TM, Nasraway S, Levy H, Bone R, Wenzel RP, Balk R, Allred R, Pennington JE, Wherry JC, for the TNF- $\alpha$ MAb Sepsis Study Group 1995 Efficacy and safety of monoclonal antibody to human tumor necrosis factor $\alpha$ in patients with sepsis syndrome. A randomized, controlled, double-blind, multicenter clinical trial. JAMA 273:934-941

20. Dinarello CA 1991 The proinflammatory cytokines interleukin-1 and tumor necrosis factor and treatment of the septic shock syndrome. J Infect Dis 163:1177-1184

21. Mancuso G, Tomasello F, Migliardo M, Delfino D, Cochran J, Cook JA, Teti G 1994 Beneficial effects of interleukin-6 in neonatal mouse models of group B streptococcal disease. Infect Immun 62:4997-5002

22. Bortolussi R, Rajaraman K, Serushago B 1992 Role of tumor necrosis factor- $\alpha$ and interferon- $\gamma$ in newborn host defense against Listeria monocytogenes infection. Pediatr Res 32:460-464

23. Echtenacher B, Falk W, Mannel DN, Krammer PH 1990 Requirement of endogenous tumor necrosis factor/cachectin for recovery from experimental peritonitis. J Immunol 145:3762-3766

24. van Furth R, van Zwet ThL, Buisman AM, van Dissel JT 1994 Anti-tumor necrosis factor antibodies inhibit the influx of granulocytes and monocytes into an inflammatory exudate and enhance the growth of Listeria monocytogenes in various organs. $J$ Infect Dis 170:234-237 [rec]January 6, 1995 [acpt]May 11, 1995. 